\title{
NEGATIVNI JEZIČNI PRIJENOS NA MORFOSINTAKTIČKOJ RAZINI U UČENJU SRODNIH JEZIKA: TALIJANSKOG (J2) I SPANJOLSKOG JEZIKA (J3)
}

\author{
Matea Bulić \\ Sveučilište u Zadru
}

\begin{abstract}
Ovaj rad bavi se pojavom negativnog jezičnog prijenosa na morfosintaktičkoj razini u procesu učenja srodnih jezika talijanskog (J2) i španjolskog (J3) uzrokovanog međujezičnim utjecajem koji se javlja kod učenika čiji je materinski jezik hrvatski. Upravo zbog bliskosti iste jezične skupine često dolazi do pogrešnog stava i pretpostavke da učenici talijanskog jezika pri učenju španjolskog neće imati većih poteškoća i da će ga usvojiti s lakoćom. Međutim, zbog prividnih sličnosti dolazi do negativnog jezičnog prijenosa $\mathbf{i}$ javlja se tendencija miješanja što dovodi do fosiliziranih pogrešaka. Cilj ovog rada bio je ustanoviti pojavu negativnog jezičnog prijenosa u određenim gramatičkim strukturama $i$ najčešće morfosintaktičke pogreške pri pismenom izražavanju na španjolskom jeziku. Rad uključuje rezultate istraživanja koje je provedeno s učenicima talijanskog i španjolskog jezika. U istraživanju su se ciljano testirali određeni morfosintaktički elementi u gramatičkim zadacima koji sadržavaju određene jezične strukture koje su najčešći uzrok pogrešaka. Rezultati istraživanja potvrdili su pretpostavku da će učenici, zbog utjecaja talijanskog jezika i nedovoljne osviještenosti o problematici srodnih jezika, praviti u određenim jezičnim strukturama morfosintaktičke pogreške koje su posljedica negativnog jezičnog prijenosa. Prikupljene su morfosintaktičke pogreške u zadacima sistematizirane $i$ analizirane. Rezultati ovog rada ukazuju na osjetljivost učenja dvaju srodnih jezika te se stoga smatra kako bi se trebala pridavati veća pozornost određenim problematičnim jezičnim strukturama $u$ okviru učenja i poučavanja španjolskog i talijanskog jezika kao stranog jezika te primijeniti kontrastivni pristup koji predstavlja jednu od najprikladnijih nastavnih strategija za učitelje i učenike koji se suočavaju s izazovom učenja srodnih jezika.
\end{abstract}

Ključne riječi: negationi jezični prijenos, međujezični utjecaj, kontrastioni pristup.

\section{UVOD}

Važnost učenja stranih jezika zbog povećane pokretljivosti modernog i globaliziranog svijeta postala je sve veća i učenje više od dva jezika nije više izuzetan slučaj već prijeko potreban alat u različitim komunikacijskom kontekstima. Međutim, učenje više jezika složen je proces koji uključuje velike napore u učenju i samoj primjeni stečenog znanja.

Iako dvojezični ili višejezični govornici imaju prednost u uporabi više jezika u različitim komunikacijskim kontekstima, u mnogim slučajevima

\footnotetext{
mbulic@unizd.hr
} 
javljaju se poteškoće tijekom prelaska s jednog jezika na drugi. Ustvari, govornici se često koriste znanjem prvog jezika ili bilo kojeg drugog usvojenog jezika služeći se procesima prijenosa kao strategijama učenja s ciljem nadoknađivanja nedostatka znanja u ciljnom jeziku koje dovode do olakšanog ovladavanja učenja jezika (Medved Krajnović, 2010). Učinci prijenosa mogu biti pozitivni, što dovodi do bržeg ovladavanja ciljnim jezikom, ali i negativni, što dovodi do pogrešaka.

Tijekom mnogo godina, u području dvojezičnosti, uzimao se u obzir samo utjecaj prvog jezika (J1) kao glavnog izvora utjecaja na učenje drugog jezika (J2). Međutim, novija istraživanja pokazala su da prvi jezik nije uvijek glavni izvor prijenosa, ali i da naknadno naučeni jezici mogu također imati veliki utjecaj na učenje ciljnog jezika. Konačno, posljednja istraživanja omogućila su priznavanje usvajanja trećih jezika kao nezavisne znanstvene grane u području ovladavanja inim jezicima (Fessi, 2014).

\section{TEORIJSKA I EMPIRIJSKA POLAZIŠTA}

\subsection{Transferencija u usvajanju trećih jezika}

Premda je prijenos definiran kao rezultat sličnosti i razlika između ciljnog jezika i bilo kojeg drugog, prethodno usvojenog jezika, veći broj međujezičnih istraživanja uglavnom se bavi utjecajem prvog jezika (J1) u procesu usvajanja drugog jezika (J2) (Odlin, 1989, u Letica i Mardešić, 2007). Za prvi se jezik odavno smatralo da predstavlja ključni izvor prijenosa, te se u većini istraživanja prijenosa polazilo od pretpostavke da prvi jezik ima utjecaj na drugi jezik (Ortega, 2008). Međutim, u samom procesu ovladavanja inim jezikom događa se često da učenici u pokušaju nadoknađivanja nedostatka znanja jezika, posežu za znanjem drugih prethodno usvojenih jezika. U tom slučaju riječ je o lateralnom prijenosu, tj. prijenosu iz drugog jezika (J2) u treći jezik (J3) (Dewaele, 1998, Williams \& Hammarberg, 1998, u Letica i Mardešić 2007).

Istraživanja o jezičnom utjecaju u procesu usvajanja J3 mnogo su složenija od istraživanja usvajanja J2 jer uključuju sve procese vezane za J3 kao i sve moguće složene odnose koji se mogu pojaviti između već usvojenih jezika i jezika koji su u procesu usvajanja. Drugim riječima, u slučaju procesa usvajanja J3, ide se dalje od samog utjecaja J1 na utjecaj usvajanja J2, nastojeći dati odgovor na svu složenost fenomena. Usvajanje J3 igra važnu ulogu u području višejezičnosti i području usvajanja trećih jezika. Iz psihološke perspektive, istraživanja o usvajanju J3 predstavljaju specifičan fenomen koji proizlazi iz činjenice da učenici trećeg jezika posjeduju posebno iskustvo i složeniju sposobnost nego jednojezični govornici (Sharwood Smith i Kellerman, 1986). 
Procesi usvajanja trećih jezika koji se događaju u kognitivnim procesima učenika slični su procesima koji karakteriziraju učenike J2, dakle govorimo o dva sustava koji imaju recipročni utjecaj (prvi jezik na drugi) i koji je dao velik broj istraživanja. $S$ druge strane, u procesu ovladavanja trećih jezika postoje dvosmjerni odnosi. Treći jezik može utjecati na prvi ili na bilo koji jezik prethodno usvojen (Cenoz, 2001). Stoga, ovladavanje J3 uključuje i procese vezane za ovladavanje J2 i složenije odnose između već naučenih jezika. Prema onome što je već rečeno, važno je razlikovati učenike drugih i trećih jezika, budući da učenici trećih jezika imaju veće iskustvo i različite vrste kompetencija.

Dosadašnja su istraživanja pokazala da znanje drugog jezika također može biti izvor prijenosa u trećem jeziku, čime je utvrđeno i da prvi jezik nije uvijek dominantan izvor prijenosa (Ringbom 1987; Cenoz 2001; Hammarberg 2003; Ortega:2008). Međutim, budući da su procesi međujezičnog utjecaja obilježeni složenošću procesa, a istraživanja u području lateralnih prijenosa relativno novije prirode, još uvijek ima mnogo pitanja na koja je potrebno dati odgovor.

\subsection{Faktori koji uvjetuju prijenos u usvajanju trećih jezika}

Među faktorima koji mogu uvjetovati prijenos u usvajanju trećih jezika možemo istaknuti tipološku udaljenost između jezika i psihotipologiju. Primjerice, jezična udaljenost talijanskog i španjolskog jezika, koji pripadaju romanskoj skupini jezika, mnogo je manja nego između hrvatskog i španjolskog ili talijanskog i hrvatskog. Na taj način, vjerojatnost pojave prijenosa između tipološki bližih jezika bit će mnogo veća. Premda u prvim fazama učenja prevladava pozitivan prijenos koji olakšava proces učenja, zahvaljujući velikoj sličnosti između jezika javlja se osjećaj lakoće ovladavanja, no u kasnijim fazama učenici se često povode lažnim analogijama i na kraju dolazi do pogrešaka koje se s vremenom mogu fosilizirati i kristalizirati (Calvi, 2004). Pojam percepcije udaljenosti i subjektivne percepcije učenika o tipološkoj blizini dvaju jezičnih sustava utječe na proces usvajanja srodnih jezika. U ovom slučaju, broj elemenata koji se prenosi s jednog jezika na drugi ne ovisi samo o sličnostima koje postoje između jezika, već i o stvaranju pretpostavki o subjektivnoj tipološkoj blizini dvaju jezičnih sustava. Percepcijom udaljenosti u slučaju srodnih jezika, ponekad dolazi do prijenosa određenih struktura koje obično nisu prenosive (Rast, 2012). Aspekt subjektivne percepcije uglavnom se veže uz Kellermana (1977, 1978 u Rast, 2012) koji drži da je percepcija udaljenosti i percepcija o mogućim prenosivim elementima ključni element prijenosa struktura s jednog jezika na drugi. Uvodi pojam psihotipologija, koji se odnosi na subjektivnu percepciju između razlika i sličnosti između jezika. Kellerman ističe kognitivne procese koji imaju vrlo važnu ulogu u učenju stranog jezika. Prema Kellermanu 
(1977 u Rast, 2012), postoje tri glavna čimbenika koji međusobno djeluju određujući količinu međujezičnog utjecaja: psihološka struktura prvog jezika, percepcija udaljenosti između prvog i drugog jezika i drugog i ciljnog i njegovo poznavanje ciljnog jezika. Ako uzmemo u obzir učinke psihotipologije na lingvističke procese učenja, pitanje lingvističke tipologije također treba biti uključeno. Drugim riječima, lingvistička tipologija koja odgovara objektivnoj sličnosti između jezika preklapa se sa psihotipologijom, to jest sa subjektivnom sličnošću koju učenik percipira između njih.

$S$ obzirom na to da se učenici koriste psihotipologijom kao glavnom strategijom u procesu približavanja ciljnom jeziku, pretpostavlja se da će percipirana udaljenost između tipološki sličnih jezika biti minimalna što dovodi do toga da se jezični elementi prenose lakše. Sukladno rečenom, u ranim fazama učenja dolazi do bržeg napretka, što daje pozitivan stav zahvaljujući dobrom razumijevanju i osjećaju lakoće savladavanja jezika (Calvi, 2004). Možemo zaključiti da je traženje sličnosti između jezičnih sustava ključni postupak u procesu učenja. Učenje novih stvari prirodni je postupak koji uspostavlja veze između novih zadaća i onih koji već postoje u ljudskom umu (Ringbom, 2007 u Rast, 2012).

\subsection{Višejezičnost $i$ višejezični govornici}

Zadnjih nekoliko godina profil učenika stranih jezika značajno se promijenio i učenje trećih jezika u velikom je broju zemalja svijeta postala svakodnevna i uobičajena pojava. Stoga danas možemo govoriti o višejezičnom obrazovanju koje uključuje i prihvaćanje izazova tijekom procesa učenja zbog same složenosti njegove prirode. Unatoč nedostatku studija o višejezičnim učenicima kojima bi se potvrdile karakteristike višejezičnih govornika, Gutiérrez (2013: 176) navodi niz općih karakteristika učenika trećeg jezika. Prvo govori o prednostima koje posjeduju višejezični govornici i definira ih kao stručnjake za učenje jezika jer je njihova kognitivna i praktična razina znanja razvijenija, posebno kod pojedinaca koji imaju naprednu razinu znanja drugih stranih jezika. Budući da se radi o višejezičnim učenicima, znanje drugih stranih jezika ima određeni utjecaj na njihovu motivaciju i njihovu perspektivu u procesu učenja. Međutim, prisutnost međujezičnih utjecaja je neizbježna, što s jedne strane pogoduje učenju, zahvaljujući prethodnom poznavanju jezika, ali s druge strane, javljaju se i prepreke, zbog znanja drugih jezika, u ovom slučaju onih koji su slični španjolskom. Stoga srodni jezici mogu poslužiti kao usporedba i potvrda, zbog svog sličnog jezičnog sustava.

Kao što smo već naveli, raznolikost i složenost karakteriziraju procese i nastavu učenja trećih jezika. Gore navedene karakteristike višejezičnih učenika pripisuju se prije svega učenicima trećih jezika, odnosno višejezičnim osobama koje su uronjene u novi kontekst heterogenog društva. Možemo reći 
da se radi o autonomnijim učenicima koji učiteljsku ulogu strože ocjenjuju, jer već poznaju put učenja.

\section{4. Španjolski i talijanski: sličnosti i razlike}

Smatra se da su od svih romanskih jezika španjolski i talijanski najsličniji. Percepcija sličnosti uglavnom je rezultat usmenog razumijevanja zbog savršene ekvivalencije vokalnih sustava, istog reda riječi, gramatičkih i leksičkih analogija koje olakšavaju usvajanje već pri prvim kontaktima dvaju jezika. Velika sličnost između dvaju jezika dovodi do navodne lakoće usvajanja i na usmenoj i na pisanoj razini, što stvara osjećaj razumijevanja i sposobnosti komunikacije bez ulaganja previše napora (Calvi, 2004). Ako je tipološka udaljenost između jezika koji pripadaju istoj skupini manja, to će pogodovati bržem učenju zahvaljujući odnosima sličnosti. Upravo te sličnosti u ranoj fazi olakšavaju tijek učenja, ali u kasnijim fazama često uzrokuju različite prepreke koje ometaju razvoj međujezika.

Kako bismo okarakterizirali velike sličnosti tih dvaju jezičnih sustava, često upotrebljavamo izraz dvosjekli mač, što jasno ukazuje na nedostatke i prednosti koje podrazumijevaju (Bini i Guil, 2002). Tako je početni pristup učenika ciljnog jezika optimističan, jer stvara osjećaj sposobnosti komuniciranja s minimalnim jezičnim sposobnostima zahvaljujući sličnostima koje su često varljive, kao što su pokazale identične riječi i izrazi koji ustvari izražavaju različita značenja (Calvi, 1995). Upravo zahvaljujući percepciji udaljenosti koja pogoduje prijenosu, u prvoj fazi učenja prevladava pozitivan prijenos, ali u sljedećim fazama učenici se često povode lažnim analogijama koje dovode do pojave negativnog prijenosa. Iz toga proizlazi da odnos između srodnih jezika može biti izvor pogrešaka koje se mogu fosilizirati i kristalizirati tijekom vremena.

\subsection{Dosadašnja istraživanja međujezičnih pogrešaka u učenju španjolskog $i$ talijanskog jezika}

Unatoč učestalosti fosiliziranih pogrešaka u produkciji učenika tipološki bliskih jezika (talijanskog i španjolskog), malo je istraživanja provedeno o jezičnim prijenosima među tim srodnim jezicima. Prije nego što prijeđemo na naše istraživanje, kojim namjeravamo utvrditi najučestalije morfosintaktičke pogreške u produkciji tih jezika od strane hrvatskih govornika, predstavit će se tri rada koja su usmjerena na produkcije španjolskih, talijanskih i hrvatskih učenika španjolskog jezika, a koji su poslužili kao polazna točka u našem istraživanju.

Atzori (2006, u Bailini, 2015) je provela istraživanje analize pogrešaka u pisanoj produkciji grupe studenata sa Sveučilišta u Torinu na temelju korpusa od trinaest sudionika čiji je prvi jezik talijanski. Glavni ciljevi njezina rada bili 
su istražiti i dublje proučiti najproblematičnija područja učenja španjolskog kao stranog jezika, uzevši u obzir leksički, morfosintaktički i semantički aspekt. Rezultati analize pogrešaka u tom istraživanju pokazali su da učenici čiji je talijanski prvi jezik imaju početne prednosti zbog bliskog odnosa dvaju jezika i pretpostavljenog afiniteta koji im omogućuje brže napredovanje, ali i zastoj u različitim fazama učenja. Tako su se pojavile grafičko-fonološke, morfosintatičke i leksičko-semantičke pogreške. Kada je riječ o leksičkosemantičkim pogreškama, zabilježen je velik broj pogrešaka zbog znanja prvog jezika, što pokazuje da su se koristili procesima prijenosa kao stalnom strategijom u učenju jezika koji je toliko blizak talijanskom. Atzori ukazuje na važnost uporabe kontrastivnog pristupa smatrajući ga ključnim alatom u učenju srodnih jezika.

$\mathrm{U}$ istraživanju negativnog jezičnog prijenosa između španjolskog i talijanskog jezika u usmenoj i pisanoj produkciji učenika koji su govornici španjolskog jezika, a uče talijanski u prvom, drugom i četvrtom razredu srednje škole E. Fermi della Scuola Statale Italiana u Madridu, Maggioni (2010) kontrastivnom perspektivom utvrđuje pogreške učinjene zbog međusobnog utjecaja spomenutih jezika. Rezultati istraživanja pokazali su da se jezično miješanje očitovalo na svim razinama jezika: fonološkoj, morfološkoj, sintaktičkoj, leksičkoj i pragmatičkoj. Iako je razina nekih učenika odgovarala razini $\mathrm{C} 1$, evidentirana je trajnost i pojavnost istih pogrešaka na leksičkoj i morfosintaktičkoj razini koje ustvari odgovaraju početnim razinama učenja. Dokazano je da su neke vrste pogrešaka fosilizirane te se upozorilo na potrebu razvoja strategija za njihovo otklanjanje i izbjegavanje u budućnosti.

Perić i Novak Milić (2017) istražile su međujezične pogreške na leksičkoj razini u pisanoj produkciji kod učenika španjolskog (L3) čiji je prvi jezik hrvatski, a drugi engleski. Pretpostavile su da će do jezičnog prijenosa doći zbog formalne sličnosti između određenih elemenata $u$ jezicima $i$ da će $u$ tom slučaju engleski jezik (L2) biti vjerojatniji izvor prijenosa zbog sličnijih formalnih struktura sa španjolskim jezikom. Također su pretpostavile da se proizvodnja kalkova povećava na višim razinama jezika. Metodom analize pogrešaka potvrđene su pretpostavke da je i engleski jezik (L2) sa svojim određenim sličnim obilježjima bio glavni izvor prijenosa u pisanoj produkciji učenika španjolskog jezika.

Rezultati prikazanih istraživanja pokazali su da su se pogreške pri učenju španjolskog i talijanskog pojavile u svim aspektima tradicionalne gramatike. Dokazano je i da su se učenici koristili istim strategijama i radili karakteristične pogreške. Istraživači su zaključili da međujezične pogreške uzrokuju stagnaciju u učenju i da kontrastivni pristup predstavlja jedan od nužnih alata u poučavanju i učenju srodnih jezika.

Uzevši u obzir složenost procesa prijenosa, ovaj rad ne može odgovoriti na sva postojeća pitanja povezana s fenomenom prijenosa. Osnovna je svrha 
rada pojasniti određene poteškoće do kojih dolazi zbog negativnog jezičnog prijenosa, a koje često dovode do fosiliziranih pogrešaka koje prave učenici srodnih jezika.

\section{ISTRAŽIVANJE}

\subsection{Cilj istraživanja}

Cilj istraživanja bio je otkriti, klasificirati i objasniti najčešće morfosintaktičke pogreške u pisanoj produkciji hrvatskih učenika koji uče španjolski jezik, uzevši u obzir njihovo prethodno poznavanje talijanskog jezika, te otkriti koji su stavovi učenika o učenju španjolskog i kojim se strategijama učenja koriste. Na taj smo način htjeli odrediti morfosintaktička područja koja višejezičnim učenicima španjolskog predstavljaju najveće poteškoće i često dovode do ponavljanja istih pogrešaka, odnosno do procesa fosilizacije.

\subsection{Sudionici}

Navedeno istraživanje provedeno je u akademskoj godini 2015./2016. U istraživanju je sudjelovalo ukupno 40 hrvatskih učenika, $90 \%(\mathrm{~N}=38)$ sudionika bilo je ženskog spola, a $10 \%(\mathrm{~N}=2)$ muškog. Što se tiče dobne strukture, sudionici su bili u dobi između 15 i 29 godina, u prosjeku 22 godine. Svim je sudionicima hrvatski prvi jezik. U vrijeme istraživanja, sudionici su učili španjolski jezik između jedne i četiri godine, tj. prosječno učenje španjolskog iznosilo je 2,5 godine. Talijanski su učili između jedne i osam godina, prosječno 4,5. Govoreći o stranim jezicima, $80 \%$ sudionika $(\mathrm{N}=36)$ govori dva strana jezika, a $20 \%(\mathrm{~N}=4)$ govori tri strana jezika. $\mathrm{S}$ obzirom na to da se $\mathrm{u}$ istraživanju nisu uzeli u obzir i drugi jezici osim talijanskog i španjolskog, prema redoslijedu učenja talijanskog i španjolskog jezika, talijanski je ispitanicima bio J2, a španjolski J3.

\subsection{Instrumenti i postupci}

U ovom smo istraživanju primijenili upitnik kojim smo saznali stavove učenika o utjecaju talijanskog u procesu učenja španjolskog jezika i gramatički test u kojem su se ciljano testirali određeni morfosintaktički elementi.

$\mathrm{Na}$ početku istraživanja sudionici su pružili svoje osobne podatke dob, spol, trajanje učenja talijanskog i španjolskog te poznavanje ostalih jezika. Gramatički se test sastojao od zadataka koji su bili oblikovani tako da su se njima mogli prikupiti podaci o najučestalijim morfosintaktičkim pogreškama koje prave sudionici u španjolskom jeziku. U drugom dijelu istraživanja sudionici su trebali ispuniti upitnik sastavljen od 23 tvrdnje (vidi tablicu 1). Osim utjecaja talijanskog jezika na učenje španjolskog, tvrdnje su se odnosile i na strategije učenja kojima se učenici koriste u procesu usvajanja 
španjolskog jezika oslanjajući se na prethodno poznavanje talijanskog jezika. Na svakoj tvrdnji sudionici su izražavali svoj stav na Likertovoj ljestvici od pet stupnjeva pri čemu je broj 1 označavao potpuno neslaganje, a broj 5 potpuno slaganje. Upitnik je ispunilo 20 sudionika.

\subsection{Rezultati i diskusija}

U korpusu je prikupljeno 420 pogrešaka uzrokovanih negativnim jezičnim prijenosom koje su raspoređene po sljedećim kategorijama: prijedlozi $(41 \%)$, glagol (17\%), član (36\%) i pridjevi (6\%). Pokazalo se da prijedlozi zauzimaju prvo mjesto u broju pogrešaka i čine čak $41 \%$ ukupnih morfosintaktičkih pogrešaka, dok pridjevi sa $6 \%$ zauzimaju zadnje mjesto. U primjerima će se predstaviti neke od najučestalijih pogrešaka.

a) Član

U analizi korpusa pogrešaka otkriveno je 156 pogrešaka u kategoriji član koje predstavljaju $36 \%$ morfosintaktičkih pogrešaka. Rezultati dobiveni analizom korpusa pokazuju da hrvatski učenici najviše griješe u odabiru člana imenica i uporabi odgovarajućeg prijedloga. Svi su ispitanici barem jednom pogriješili u odabiru odgovarajućeg člana imenica koje zahtijevaju oblik člana za gramatički rod različit od roda u talijanskom jeziku. To pripisujemo velikoj sličnosti između imenica koje su ortografski, fonološki i semantički iste ili jako slične, ali zahtijevaju drugi član.

(1a) španjolski međujezik: el sal, el sangre, el nariz, el cárcel, el miel, la tigre, el señal

(1b) oblici u talijanskom jeziku: il sale, il sangue, il naso, il carcere, il miele, la tigre, il segnale

(1c) oblici u španjolskom jeziku: la sal, la sangre, la nariz, la cárcel, la miel, el tigre, la señal

b) Prijedlog

Uporaba prijedloga obično uzrokuje različite poteškoće, budući da veoma slični glagoli koji postoje u oba jezika zahtijevaju različite prijedloge. Te prividne sličnosti glagola rezultirale su velikim brojem pogrešaka u uporabi prijedloga koje, ujedno, predstavljaju najveći broj uočenih morfosintaktičkih pogrešaka. Krivi odabir prijedloga u svom španjolskom međujeziku često se uočava kod hrvatskih učenika španjolskog jezika i predstavlja jedno od najproblematičnijih područja. Naime, postoji velik broj izraza i glagola koji se u talijanskom i španjolskom jeziku podudaraju na ortografskoj i semantičkoj razini, ali zahtijevaju različite prijedloge. Na primjer, iako talijanski prijedlozi DI i DA za izricanje istih funkcija odgovaraju španjolskom prijedlogu DE, postoje izrazi i glagoli koji zahtijevaju drugi prijedlog: chiedere di qualcuno 
$\rightarrow$ preguntar por alguien, essere in viaggio $\rightarrow$ estar de viaje. Uporaba prijedloga A i EN u španjolskom jeziku ovisi o tipu glagola koji izriču dostizanje cilja kretanja (voy a Barcelona), dok oni koji izriču mjesto u unutrašnjosti nečega idu s prijedlogom EN (estoy en Madrid). S druge strane, u talijanskom, odabir glagola ne ovisi samo o vrsti glagola nego i o vrsti imenice koja ide nakon prijedloga pa će tako biti: vado a Barcellona, sono a Madrid. U dijelu uporabe prijedloga zabilježeno je 176 pogrešaka koje čine 41 \% ukupnih pogrešaka zbog čega se može zaključiti da uporaba prijedloga predstavlja veće teškoće u učenju španjolskog jezika. Ti nas rezultati dovode do zaključka da se hrvatski učenici moraju suočiti ne samo sa složenošću uporabe prijedloga u obama jezicima već ih trebaju znati razlučiti i pravilno se njima koristiti u svakom jeziku.

(2a) španjolski međujezik: tengo miedo de los perros, estoy en viaje, se va in Italia, saber a memoria, solo si te pones en rodillas, vivo a Zagreb, tenemos que ir dal medico, estoy a Barcelona, vivimos cerca a tu casa

(2b) oblici u talijanskom jeziku: ho paura dei cani, sono in viaggio, va in Italia, sapere a memoria, solamente se ti metti in ginocchia, vivo a Zagreb, dobbiamo andare dal dottore, sono a Barcellona, viviamo vicino alla tua casa

(2c) oblici u španjolskom jeziku: tengo miendo a los perros, estoy de viaje, se va a Italia, solo si te pones de rodillas, vivo en Zagreb, tenemos que ir al médico, estoy en Barcelona, vivimos cerca de tu casa

c) Glagol

U kategoriji glagola registrirano je 68 pogrešaka, što predstavlja $16 \%$ morfosintaktičkih pogrešaka. Najviše se griješilo u pravilnoj upotrebi prošlih svršenih vremena, povratnih glagola, oblika za niječni imperativ, razlikovanja ser/haber, estar/haber i haber/tener. Pogreške koje se odnose na uporabu prošlih vremena povezane su s krivim odabirom za izražavanje svršene radnje. Otkriveno je čak 15 pogrešaka kojima je uzrok to da su se sudionici odlučili za talijansku varijantu umjesto za španjolsku. Uočeno je također da povratni glagoli ponekad predstavljaju poteškoće, budući da neki glagoli koji su u talijanskom povratni u španjolskom nisu i obrnuto. Isto tako, bilo je pogrešaka i u niječnom imperativu, gdje su se sudionici odlučili za talijanski oblik u svom španjolskom međujeziku. Također su zamijećene pogreške nastale uslijed zamjene glagola tener/haber, estar/haber i ser/haber. Miješanje glagola tener i haber proizlazi izučestalog učeničkog poistovjećivanja španjolskog glagola haber $\mathrm{s}$ talijanskim avere koji se $\mathrm{u}$ talijanskom koristi za izražavanje posjedovanja i kao pomoćni glagol u složenim vremenima, dok se u španjolskom glagol haber upotrebljava samo kao pomoćni glagol u konjugaciji složenih vremena. Za izražavanje posjedovanja, u španjolskom se koristimo glagolom tener. Jedna od najkarakterističnijih razlika između tih dvaju jezika jest što talijanski ima dva pomoćna glagola (essere i avere) za 
tvorbu prošlih vremena dok španjolski ima samo jedan (haber). S druge strane španjolski jezik ima dva oblika glagola biti, a to su ser i estar koji odgovaraju jednom talijanskom obliku essere. Kao što je već rečeno, u španjolskom jeziku, glagol haber koristi se kao pomoćni glagol, dok se u talijanskom jeziku koristimo dvama glagolima za formiranje prošlih vremena. Primijećeno je da se učenici, povodeći se analogijom, u svom španjolskom međujeziku umjesto glagola haber za tvorbu prošlih vremena, koriste španjolskim glagolom ser (tal. essere) npr. s glagolima kretanja, povratnim glagolima koji u talijanskom idu s essere. Osim svoje funkcije pomoćnog glagola, glagol haber može se koristiti u svom bezličnom obliku kao oblik hay i odgovara talijanskom esserci: hay mucha gente $\rightarrow c^{\prime} e^{\prime}$ molta gente. U tom se slučaju učenici umjesto oblikom hay koriste španjolskim glagolom estar ili ser koji odgovaraju talijanskom glagolu essere.

(3a) španjolski međujezik (perfekt/aorist): He comprado este coche hace tres años. Ho visto tu padre ayer.

(3b) tal: Ho comprato questa macchina tre anni fa. Ho visto tuo padre ieri.

(3c) španj.: Compré este coche hace tres años. Vi a tu padre ayer.

(4a) španjolski međujezik (estar/haber): Aquí están muchos bares. Está un hospital.

(4b) tal: Qua ci sono molti bar. C'e' un ospedale.

(4c) špa: Aquí hay muchos bares. Hay un hospital.

(5a) španjolski međujezik (povratni glagoli): Me descansé, me he descansado, he rimasto en casa.

(5b) tal: Mi sono riposato, sono rimasto a casa.

(5c) španj: Descansé, me quedé en casa.

(6a) španjolski međzjezik (niječni imperativ): No hablar más!!

(6b) tal.: Non parlare più!

(6c) španj: ¡No hables más!

(7a) španjolski međujezik (ser/haber): Soy llegado.

(7b) tal: Sono venuto.

(7c) španj: He venido.

(8a) španjolski međujezik (haber/tener): Habemos la tarea. Habéis un perro grande.

(8b) tal: Abbiamo il compito.Avete un cane grande.

(8c) španj: Tenemos la tarea. Tenéis un perro grande.

Premda nismo obuhvatili sve morfosintaktičke aspekte koji se mogu manifestirati međujezičnim pogreškama, tj. pogreškama koje se događaju tijekom učenja španjolskog kao trećeg jezika, a pod utjecajem talijanskog kao drugog jezika, nastojali smo odrediti područja koja smatramo najproblematičnijima u procesu učenja srodnih jezika. Rezultati istraživanja 
pokazali su nam da su morfosintaktičke pogreške vidljive i višestruke te da uporaba prijedloga i članova stvara veće teškoće zbog djelomičnih razlika između jezika i lažnih analogija. Smatramo da krive produkcije u J3 s psiholigvističkog stajališta otkrivaju aktivni proces učenja u kojem učenici primjenom strategija učenja nesvjesno pribjegavaju uporabi prethodno naučenog znanja jezika u svrhu približavanja ciljnom jeziku.

Nadalje, cilj je istraživanja bio otkriti stavove ispitanika o utjecaju talijanskog na proces učenja španjolskog. Pretpostavljeno je da su sudionici bili svjesni da im je prethodno poznavanje talijanskog olakšalo učenje španjolskog jezika. Tablica 1 prikazuje rezultate deskriptivne analize podataka prikupljenih upitnikom. Kako bi se dobio uvid u opće stavove sudionika, izračunata je srednja vrijednost za svaku afirmativnu tvrdnju.

Tablica 1. Rezultati deskriptione statistike $(N=20)$

\begin{tabular}{|l|c|c|c|c|c|c|c|}
\hline Tvrdnja & Nikad & Rijetko & Ponekad & Često & Uvijek & AS & SD \\
\hline $\begin{array}{l}\text { 1. Smatram da mi znanje talijanskog } \\
\text { jezika olakšava proces učenja } \\
\text { španjolskog jezika. }\end{array}$ & 0 & 0 & 6 & 9 & 5 & 3,95 & 0,75 \\
\hline $\begin{array}{l}\text { 2. Znanje talijanskog jezika motivira } \\
\text { me na učenje španjolskog jezika. }\end{array}$ & 1 & 1 & 8 & 5 & 5 & 3,60 & 1,09 \\
\hline $\begin{array}{l}\text { 3. Španjolski jezik sličniji je } \\
\text { talijanskom nego hrvatskom jeziku. }\end{array}$ & 0 & 0 & 0 & 2 & 18 & 4,90 & 0,30 \\
\hline $\begin{array}{l}\text { 4. Smatram da lakše usvajam } \\
\text { španjolski jezik od kolega koji nisu } \\
\text { učili talijanski jezik. }\end{array}$ & 0 & 0 & 5 & 7 & 8 & 4,15 & 0,81 \\
\hline $\begin{array}{l}\text { 5. Smatram da mi znanje talijanskog } \\
\text { na višim razinama ometa učenje } \\
\text { španjolskog. }\end{array}$ & 0 & 4 & 8 & 7 & 1 & 3,25 & 0,85 \\
\hline $\begin{array}{l}\text { 6. Da mogu vratiti vrijeme, uz } \\
\text { španjolski ne bih učio/la talijanski, } \\
\text { već neki drugi strani jezik iz druge } \\
\text { jezične porodice. }\end{array}$ & 11 & 3 & 4 & 2 & 0 & 1,85 & 1,08 \\
\hline $\begin{array}{l}\text { 7. Katkad se na satu španjolskog } \\
\text { nesvjesno izrazim na talijanskom } \\
\text { jeziku pri pismenom izražavanju. }\end{array}$ & 0 & 2 & 8 & 7 & 3 & 3,55 & 0,88 \\
\hline $\begin{array}{l}\text { 8. Kad se želim pismeno izraziti } \\
\text { na španjolskom, razmišljam na } \\
\text { talijanskom jeziku. }\end{array}$ & 1 & 6 & 8 & 3 & 2 & 2,95 & 1,05 \\
\hline $\begin{array}{l}\text { 9. Svjestan/na sam da pri pismenom } \\
\text { izražavanju na španjolskom jeziku } \\
\text { pogriješim zbog znanja talijanskog } \\
\text { jezika. }\end{array}$ & 1 & 3 & 7 & 8 & 1 & 3,25 & 0,96 \\
\hline $\begin{array}{l}\text { 10. Kad pri pismenom izražavanju } \\
\text { na španjolskom jeziku pogriješim } \\
\text { zbog znanja talijanskog jezika, } \\
\text { odmah se ispravim. }\end{array}$ & 1 & 2 & 7 & 7 & 3 & 3,45 & 1,05 \\
\hline
\end{tabular}




\begin{tabular}{|l|c|c|c|c|c|c|c|}
\hline $\begin{array}{l}\text { 11. Strah me je da se ne izrazim na } \\
\text { talijanskom jeziku pri pismenom } \\
\text { izražavanju na španjolskom jeziku. }\end{array}$ & 1 & 6 & 2 & 8 & 3 & 3,30 & 1,21 \\
\hline $\begin{array}{l}\text { 12. Ukoliko se izrazim na } \\
\text { talijanskom jeziku pri pismenom } \\
\text { izražavanju, zapišem pogrešku } \\
\text { kako se ona ne bi ponovila. }\end{array}$ & 8 & 5 & 6 & 0 & 1 & 2,05 & 1,09 \\
\hline $\begin{array}{l}\text { 13. Frustriraju me pogreške na } \\
\text { španjolskom jeziku koje uradim } \\
\text { zbog utjecaja talijanskog jezika. }\end{array}$ & 5 & 4 & 3 & 4 & 4 & 2,90 & 1,51 \\
\hline $\begin{array}{l}\text { 14. Smatram da je talijanska } \\
\text { gramatika jako slična španjolskoj } \\
\text { gramatici. }\end{array}$ & 3 & 0 & 4 & 10 & 3 & 3,50 & 1,23 \\
\hline
\end{tabular}

Kao što je vidljivo iz rezultata prikazanih u tablici 1, sudionici smatraju da je španjolski bliži talijanskom nego hrvatskom (tvrdnja 3). Također smatraju da brže usvajaju španjolski jezik zbog prethodnog znanja talijanskog od kolega koji ne posjeduju znanje talijanskog (tvrdnja 4). Dakle, percepcija udaljenosti i percepcija onoga što je prenosivo ključni su elementi prijenosa struktura iz jednog jezika u drugi. Kao što vidimo, sudionici su svjesni tipološke sličnosti između španjolskog i talijanskog, što upućuje na zaključak da percepcija udaljenosti igra važnu ulogu u ovladavanju trećih jezika. Što se tiče korištenja talijanskog jezika pri učenju španjolskog jezika, sudionici smatraju da se ponekad izražavaju na talijanskom jeziku u pisanom obliku (tvrdnja 7). Zanimljivo je da unatoč preprekama i negativnom prijenosu koji karakteriziraju učenje srodnih jezika, sudionici potvrđuju da bi se opet odlučili na učenje oba jezika (tvrdnja 6). Rezultati su pokazali da sudionici uglavnom ne bilježe međujezične pogreške kako se ne bi ponovile i da samo ponekad provjeravaju rodne razlike imenica (tvrdnja 12). Navedeni rezultat upućuje na to da sudionici ne obraćaju pozornost na razlike između španjolskog i talijanskog, što često dovodi do fosilizacije pogrešaka.

\section{ZAKLJUČAK S DIDAKTIČKIM IMPLIKACIJAMA}

Društvene i gospodarske promjene u drugoj polovici dvadesetog stoljeća naglašavale su potrebe suvremenog čovjeka za učenjem sve većeg broja stranih jezika što je i dovelo do brojnih istraživanja kojima je cilj unaprijediti učenje i poučavanje jezika. Danas, u 21. stoljeću u potpunosti smo uronjeni u višejezičnost čiji se utjecaj vidi u miješanju različitih jezičnih sustava, odnosno u međujezičnom utjecaju tijekom procesa ovladavanja drugim jezicima. Drugim riječima, koncept prijenosa je neizbježan fenomen. Što se tiče učenja srodnih jezika, proces je karakteriziran pozitivnim i negativnim učincima. Velike sličnosti s jedne strane imaju pozitivan učinak $u$ procesu učenja drugog srodnog jezika, posebice u prvim fazama učenja, ali zbog lažnih analogija često dolazi do većih poteškoća u kasnijim fazama (Gutierréz, 2013). 
Stoga smatramo da bi se trebala pridati važnost uvođenju kontrastivnog opisa jezika koji predstavlja jednu od najprikladnijih nastavnih strategija za učitelje i učenike koji se suočavaju s izazovom učenja srodnih jezika. Vjerujemo da nastavnici mogu imati ključnu ulogu u procesima prijenosa između srodnih jezika stavljajući naglasak na problematična područja. $\mathrm{Na}$ taj način nastavnik može predvidjeti moguće poteškoće i smanjiti pojavu negativnog prijenosa te tako izbjeći stagnaciju u ciljnom jeziku. Smatramo da bi se primjenom kontrastivne perspektive mogao promijeniti negativan stav prema negativnom prijenosu smatrajući ga dijelom učenja, a ne samo preprekom koja usporava tijek ovladavanja jezikom.

$S$ obzirom na to da su dosadašnja iskustva u radu s učenicima koji uče srodne jezike kao što su talijanski i španjolski te ovdje opisano istraživanje potvrdili da učenici često ne bilježe pogreške zbog uspostavljanja krivih analogija, izrada nastavnih materijala koja bi se temeljila na sličnostima i razlikama između talijanskog i španjolskog jezika doprinijela bi otklanjanju i fosilizaciji pogrešaka već na početnim stupnjevima učenja jezika, i to na leksičkoj i morfosintaktičkoj razini. Nastavni materijali već za početni stupanj učenja tih jezika trebali bi uvažiti učestalost određenih gramatičkih i leksičkih kategorija, razlike u rodu sličnih imenica ispravan odabir pomoćnih glagola za tvorbu perfekta, brojne lažne prijatelje na leksičkoj razini i ostale primjere koji su navedeni u prikazanom istraživanju. Nadamo se da će ovaj rad potaknuti provedbu sličnih istraživanja i izradu nastavnih materijala koji će se temeljiti na kontrastivnom opisu jezika kako bi se poboljšalo učenje i poučavanje srodnih jezika.

\section{LITERATURA}

Bailini, S. (2015) La interlengua de lenguas afines. Milano: LED.

Bini, M. i Guil, P. (2002) Algunos puntos de contraste entre italiano y español. http://www.contrastiva.it/baul_contrastivo/dati/sanvicente/contrastiva/Morfosintaxis\%20Contrastiva/Bini\%20 Guil,\%20Italiano\%20y\%20espa\%C3\%B1ol\%20algunos\%20puntos\%20de\%20contraste.pdf (17. 10. 2015.)

Calvi, M. V. (2004) Aprendizaje de lenguas afines: español e italiano. Revista eléctronica de didáctica de ELE. http://www.mecd.gob.es/dctm/redele/Material-RedEle/Revista/2004_01/2004_redELE_1_ 02Calvi.pdf?documentId=0901e72b80e06a6d (15. 9. 2015.)

Cenoz, J. (2001) The effect of linguistic distance, L2 status and age on cross-linguistic influence in third language acquisition. U Cenoz J., Hufeisen B., i Jessner U. (ur.) (2001) Cross-Linguistic Influence in Third Language Acquisition: Psycholinguistic Perspectives. Clevedon: Multilingual Matters, 8-19.

Gutiérrez Eugenio, E. (2013) La enseñanza del español como L3. Implicaciones didácticas. Revista Instituto Cervantes. https://cvc.cervantes.es/ensenanza/biblioteca_ele/publicaciones_centros/ PDF/budapest_2013/19_gutierrez.pdf (10. 2. 2016.)

Fessi, I. (2014) Influencias interlinguisticas: desarrollos recientes. Transferencias en adquisición de tiempo y aspecto en español. Revista de Didáctica Español como Lengua Extranjera. http://marcoele.com/descargas/19/fessi-transferencias_13.pdf (11. 11. 2015.)

Hammarberg, B. (2003) Processes in Third Language Acquisition. Edinburgh: Edinburgh University Press.

Kellerman, E. (1995) Cross-Linguistic Influence: Transfer to Nowhere? Annual Review of Applied Linguistics 15, 125-150. 
Maggioni, V. (2010) L'influenza della 11 nell'apprendimento di lingue affini: analisi delle interferenze linguistiche di ispanofoni apprendenti l'italiano come lingua straniera". LinguaDue. https://riviste.unimi.it/index.php/promoitals/article/view/628/842 (1. 10. 2015.)

Medved Krajnović, M. (2010) Od jednojezičnosti do višejezičnosti. Zagreb: Leykam international d.o.o.

Perić, B. i Novak Milić, S. (2017) Cross-Linguistic Influences in Third Language Acquisition (Spanish) and the Relationship between Language Proficiency and Types of Lexical Errorsaka. Croatian Journal of Education 19 (2), 91-107. https://doi.org/10.15516/cje.v19i0.2619 (13. 10. 2020.)

Letica, S. i Mardešić, S. (2007) Cross-Linguistic Tranfer in L2 and L3 Production. U Horváth, J. i Nikolov, M. (ur.) UPRT 2007: Empirical Studies in English Applied Linguistics. Pécs: Franca Csoport. http://mek.oszk.hu/07500/07557/07557.pdf (30.9. 2015.)

Ortega, M. (2008) Cross-linguistic influence in multilingual language acquisition: The role of L1 and non-native languages in English and Catalan oral production. Ikala. Revista de Lenguaje y Cultura 13 (19). http://www.scielo.org.co/scielo.php?script=sci_arttext\&pid=S0123-34322008000100007 (8. 10. 2015.)

Rast, R. (2012) The use of prior linguistic knowledge in the early stages of L3 acquisition. International Review of Applied Linguistics in Language Teaching 48 (2-3), 4-24.

Ringbom, H. (1987) The role of the first language in foreign language learning. Clevedon: Multilingual Matters.

Sharwood M. i Kellerman E. (ur.) (1986) Cross-Linguistic Influence in Second Language Acquisition. New York: Pergamon Press.

\section{NEGATIVE LANGUAGE TRANSFER AT THE MORPHOSYN- TACTIC LEVEL WHEN LEARNING RELATED LANGUAGES: ITALIAN (J2) AND SPANISH LANGUAGE (J3)}

This paper deals with the occurrence of negative language transfer at the morphosyntactic level in the process of learning related languages, that is, Italian (J2) and Spanish (J3), which is caused by the crosslinguistic impact that occurs with students whose mother tongue is Croatian. Precisely because of the closeness of the same language group, there is often a misconception that Italian language learners will not have substantial difficulties when learning Spanish and that they will learn it with ease. However, due to seemingly similar elements, negative language transfer occurs, and there is a tendency to mix the languages, which leads to fossilized errors. The purpose of this paper was to determine the occurrence of negative language transfer in certain grammatical structures and to determine the most frequent morphosyntactic errors when writing in Spanish. The paper includes the results of the research which was conducted with Italian and Spanish language students. The research targeted specific morphosyntactic elements in grammatical tasks which contain certain linguistic structures commonly causing the errors. The results of the research have confirmed the assumption that students, due to the influence of Italian and insufficient awareness of the problem of related languages, make morphosyntactic errors in certain linguistic structures as a result of negative language transfer. The resulting morphosyntactic errors are systematized and analyzed. The results of this paper indicate the sensitive nature of learning two related languages and it is therefore believed that more attention should be given to certain problematic linguistic structures while learning and teaching Spanish and Italian as foreign languages and implement a contrastive approach, which is one of the most appropriate teaching strategies for teachers and students facing the challenges of learning related languages.

Keywords: negative language transfer, crosslinguistic influence, contrastive approach.

This work is licensed under a Creative Commons Attribution 4.0 International License.

Ovaj rad dostupan je za upotrebu pod licencom Creative Commons Imenovanje 4.0 međunarodna. 